\title{
Biodegradation of Some Dyes by The Green Alga Chlorella vulgaris and the Cyanobacterium Aphanocapsa elachista
}

\author{
Mostafa M. El-Sheekh ${ }^{(1) \#}$, Ghada W. Abou-El-Souod ${ }^{(2)}$ and Hayam A. El Asrag(2) \\ (1)Botany Department, Faculty of Science, Tanta University, Tanta, Egypt; (2)Botany \\ Department, Faculty of Science, Menoufia University, Menoufia, Egypt.
}

\begin{abstract}
A S A RESULT of its wide usage in the textile and other industries, dyes are widely detected in industrial wastewater. Algae and cyanobacteria can degrade and mineralize a number of dyes, presuming that the reduction appears to be related to the molecular structure of the dyes and the algal species used. The present study was conducted to investigate the potential of the green alga Chlorella vulgaris and the Cyanobacterium Aphanocapsa elachista isolated from polluted industrial regions for biodegradation of some pollutant dyes. The dyes used in this investigation were Disp orange 2RL, Reactive yellow 3RN, Reactive Black NN and Tracid Red BS. The results revealed that the maximum decolorization was observed in Disp. Orange 2RL (Azo dye) by Chlorella vulgaris (55.22\%) after 7 days of incubation, while, Aphanocapsa elachista decolorized reactive yellow $3 \mathrm{RN}$ (Azo dye) by 49.16\%. Azo reductase enzyme in the used alga is responsible for degradation of azo dyes into an aromatic amine by cleaving the azo linkage. The results showed that treatment of Chlorella vulgaris with Disp Orange 2RL induced the azoreductase enzyme by $62.17 \%$ and Aphanocapsa elachista with Reactive yellow $3 \mathrm{RN}$ by $52.48 \%$ after 7 days of incubation. After decolorization, the degradation products were identified and confirmed by spectroscopic analysis (FTIR, GC/MS). This work concludes the ability of some microalgae and cyanobacteria for biodegradation of environmental pollutants.
\end{abstract}

Keywords: Biodegradation, Dyes, Microalgae, Industrial wastewater, Spectroscopic analysis.

\section{Introduction}

Dye pollutants released by the textile industry are continuously causing serious harmful effects to the environment. Therefore, it is necessary to overcome this problem via biological treatments by selecting some microorganisms which are capable of biodegradating of such pollutants. After biodegradation, it is important to study the products of biodegrading synthetic dyes in order to know about the environmental destiny of these pollutants. It is very important to analyze the treated wastewater concerning the dye content as well as intermediates, especially aromatic amines since some are considered carcinogenic (Forss \& Welander, 2009). It is also necessary to characterize the intermediates compounds which may be produced during biodegradation to ensure the safety of the decolorized wastewater (Couto, 2009 and Kaushik \& Malik, 2009). In this connection, Chen et al. (2008) stated that various basic methods and advanced techniques such as chromatography and spectroscopy can be used to characterize the products of biodegradation of dyes and so have an insight into the mechanism of biodegradation. To date, very few reports are available on the intermediates or the products of biodegradation of triphenylmethane dyes. In order to attain an efficient and high biodegradation rate, the microbial community should be adapted to toxic compounds and this also useful in improving the rate of decolorization process (Dafale et al., 2008). Biological treatment requires a large area and this method is unsatisfactory in color elimination with current biodegradation processes (Robinson et al., 2001). Based on different oxygen demand, biological treatment methods are classified into aerobic and anaerobic treatment. Aerobic biological treatment is a conventional method due to its-high efficiency and wide application. The biological operation is cheaper than other methods. When compared to chemical methods, biological operation investment cost is 5-20 times less and operating costs are 3-10 times less than chemical methods (Karthik et al., 2014). Many species of Chlorella and Oscillotoria were reported to be capable of degrading azo dyes to their aromatic amines and also metabolizing the aromatic amines to simple organic compounds or $\mathrm{CO}_{2}$. Some microalgae

"Corresponding author email: mostafaelsheikh@science.tanta.edu.eg

DOI: 10.21608/ejbo.2018.2675.1145

Edited by: Prof. Dr. Salama A. Ouf, Faculty of Science, Cairo University, Cairo, Egypt.

(C)2018 National Information and Documentation Center (NIDOC) 
and cyanobacteria species were even capable of utilizing a few azo dyes as their sole source of carbon and nitrogen (Wen-Tung \& Ming-Der, 2012). Abou-ElSouod \& El-Sheekh (2016) stated that the ability of Hydrocoleum oligotrichum and Oscillatoria limnetica to decolorize and degrade methyl red and basic fuchsin depends on the dye concentration and type of organism used. The present study was carried out to investigate the ability of Chlorella vulgaris and Aphanocapsa elachista to remove and decolorize some of the most widespread industrial dyes.

\section{Materials and Methods}

\section{Algae and growth conditions}

Chlorella vulgaris and Aphanocapsa elachista were isolated from polluted locations in the industrial region in Quisna, and Sadat City, Menoufia Governorate, Egypt and purified in axenic cultures (bacterial free) as described by Bolch \& Blackburn (1996) and identified according to Pontin (1978), Prescott (1984), Yamagishi (1992) and Vymazal (1995). Aphanocapsa elachista was cultured in Allen medium (Allen, 1968) and Chlorella vulgaris on Kuhl medium (Kuhl \& Lorenzen, 1964) in sterilized Erlenmeyer conical flasks and the $\mathrm{pH}$ was adjusted to 6.8. After inoculation, they were kept in the culture room at $28 \pm 1^{\circ} \mathrm{C}$ under continuous illumination $\left(80 \pm 4 \mu \mathrm{E} / \mathrm{m}^{2} \mathrm{~s}\right)$ for $C$. vulgaris and $\left(60 \pm 4 \mu \mathrm{E} / \mathrm{m}^{2} \mathrm{~s}\right)$ for $A$. elachista.

\section{Dyes and azo dyes used}

Reactive yellow 3RN (3-carboxy-4-Hydroxy4'-nitro azobenzen), Disp.orange 2RL (4-nitro-4'[N-ethyl-N-(2-cyanoethyl)-amino]azobenzen), Reactive Black NN(1,5-diamino pentane) and Disp. Red BS (Tracid Red BS, $\mathrm{C}_{30} \mathrm{H}_{37} \mathrm{~N}_{3} \mathrm{Na}_{2} \mathrm{O}_{8} \mathrm{~S}_{2}$ ) were obtained from Dyeing Factory at the industrial region district in Quisna, Menoufia Governorate, Egypt and were used for decolorization and biodegradation study.

Decolorization study and spectroscopic analysis

Spectroscopic analysis was determined according to Telke et al. (2010):

Decolorization $(\%)=$ (Initial absorbance Final absorbance/Initial absorbance) $\times 100$.

\section{FT-IR analysis of decolorized samples}

The characterization of the biodegraded dye samples was analyzed before and after treatment with tested algae using FTIR spectroscopy (Tensor 27 Bruker, Spectrum one). The analyses of the biodegraded dyes were compared with the control dyes. The FTIR analysis was done in the mid IR region $\left(400-5000 \mathrm{~cm}^{-1}\right)$ with 16 scan speed (Sarwa \& Verma, 2013; Shyamala et al., 2014 and ElSheekh et al., 2017).

\section{Estimation of protein}

Protein was estimated by the method described by Lowry et al. (1951).

\section{Azo reductase activity}

Azoreductase activity was determined by the method adopted by Idaka et al. (1987a,b).

Gas chromatography - mass spectrometry (GCMS)

Gas chromatography - mass spectrometry (GCMS) combines two powerful techniques to provide the identification of compounds with low detection limits and the potential for quantitative analysis.

This analysis was performed before and after treatment by the dye after 7 days of incubation to determine the degradable products of dyes. Using Agilent 6890 gas chromatograph equipped with an Agilent mass spectrometric detector, with a direct capillary interface and fused silica capillary column PAS-5 ms $(30 \mathrm{~m} \times 0.32 \mathrm{~mm} \times 0.25 \mu \mathrm{m}$ film thickness). Samples were injected under the following conditions; helium was used as carrier gas at approximately $1.0 \mathrm{ml} / \mathrm{min}$., pulsed splitless mode. The solvent delay was $3 \mathrm{~min}$. and the injection size was $1.0 \mu \mathrm{m}$. The mass spectrometric detector was operated in an electron impact ionization mode with an ionizing energy of 70e.v. scanning from $\mathrm{m} / \mathrm{z} 50$ to 500 . The ion source temperature was $230^{\circ} \mathrm{C}$. The electron multiplier voltage (EM voltage) was maintained at $1650 \mathrm{v}$ above autotune. The instrument was manually tuned using per flourotributy amine (PFTBA). The $\mathrm{GC}$ temperature program was started at $60^{\circ} \mathrm{C}(2$ $\mathrm{min}$ ) they elevated to $300^{\circ} \mathrm{f}$ at a rate of $5^{\circ} \mathrm{C} / \mathrm{min}$, the injector temperature was set at $280^{\circ} \mathrm{C}$, respectively. Wiley and Wiley Nist mass spectral database were used in the identification of the separated peaks (Hadibarata et al., 2012).

\section{Statistical analyses}

The data were statistically analyzed according to SPSS program, to compare between means, standard error (SE) of three replicates, L.S.D. test at levels of $5 \%$ were used. 


\section{Results and Discussion}

Pollution of surface water by organic toxicants became seriously dangerous to the aquatic ecosystem. Organic pollution may originate from domestic or industrial effluents. One of the common organic pollutants are dyes and azo dyes which represent a long-lasting pollution threat and recognized worldwide. The discharge of organic pollutants to any water body may cause a high organic content in this aquatic ecosystems and, in the long term, to eutrophication. The pollutant dyes water can reduce water quality thus restricting the use of these water bodies for many purposes (Xu \& Nirmalakhandan, 1998; Altenburger et al., 2000 and Sen et al., 2013). The present results showed the potential of Chlorella vulgaris and the Aphanocapsa elachista to biodegrade a variety of dyes and azo dyes depending on the type of the dye and algal species.

\section{Decolonization experiments}

The decolorization of four chosen dyes by Chlorella vulgaris and Aphanocapsa elachista was studied using $20 \mathrm{ppm}$ dyes concentration after 7 days incubation. Table 1 showed that there was an increase in the decolorization rate with increasing the incubation time. Table 1 also showed that Chlorella vulgaris has a maximum percentage $(55.22 \%)$ of degradation after treatment with Disp. Orange 2RL (Azo dye) after 7 days of incubation.

The obtained results concluded that the chosen microalga and cyanobacterium have the ability to degrade and remove the color of various dyes from wastewater effluents. These observations coincide with the results of Anjaneyulu et al. (2005) who reported that the microalgae have the ability to remove the dyes color by different mechanisms of assimilative utilization of chromophore for production of algal biomass, $\mathrm{CO}_{2}$ and $\mathrm{H}_{2} \mathrm{O}$. So, resulting in the transformation of colored dye molecules to non-colored ones, and the adsorption of chromophore on algal biomass.

\section{Protein content}

The obtained results demonstrated that the protein content was increased with respect to the incubation period. As shown in Table 2, different dyes influenced protein content in Chlorella vulgaris. The protein content of this green alga showed the highest value after 7 days with Dis. Orange 2RL. Table 3 showed that the largest protein content of Aphanocapsa elachista after 7 days with Disp. Red BS.

TABLE 1. Percentage of biodegradation of different dyes and azo dyes by Chlorella vulgaris and Aphanocapsa elachista.

\begin{tabular}{lccc}
\hline \multicolumn{4}{c}{ Degradation percentage (\%) } \\
\hline Dye & Day & Chlorella vulgaris & Aphanocapsa elachista \\
\hline Disp. Orange 2RL (Azo dye ) & 3 & $41.79 \pm 1.859$ & $14.62 \pm 2.91$ \\
& 5 & $49.25 \pm 2.181$ & $20.59 \pm 0.776$ \\
Tracid red Bs & 7 & $55.22 \pm 5.439$ & $26.89 \pm 4.451$ \\
& 3 & $15.5 \pm 0.936$ & $40.51 \pm 1.322$ \\
Reactive Black NN & 5 & $28.44 \pm 1.523$ & $46.55 \pm 0.995$ \\
& 7 & $35.34 \pm 2.514$ & $48.27 \pm 0.499$ \\
Reactive Yellow 3RN (Azo dye ) & 3 & $3.61 \pm 0.960$ & $26.61 \pm 0.491$ \\
& 5 & $7.21 \pm 0.245$ & $30.42 \pm 0.324$ \\
& 7 & $9.32 \pm 0.323$ & $31.5 \pm 0.508$ \\
& 3 & $29.04 \pm 0.117$ & $43.49 \pm 0.344$ \\
& 5 & $30.48 \pm 3.292$ & $47.7 \pm 1.157$ \\
& 7 & $31.53 \pm 0.751$ & $49.16 \pm 1.591$ \\
\hline
\end{tabular}

Each value is means $\pm \mathrm{SE}(\mathrm{n}=3)$. 
TABLE 2. The effect of different dyes on the protein content of Chlorella vulgaris.

Protein content $(\mathrm{mg} / \mathrm{ml})$

\begin{tabular}{lcccc}
\hline Dyes & $\mathbf{3}$ & $\mathbf{5}$ & $\mathbf{7}$ & L.S.D* $^{*}$ \\
\hline Control & $44.62 \pm 2.15$ & $46.92 \pm 2.18$ & $49.85 \pm 1.51$ & 0.238 \\
Reactive yellow 3RN & $22.92 \pm 1.63$ & $26.0 \pm 1.23$ & $26.81 \pm 1.13$ & 0.001 \\
Disp. Orange2RL & $38.76 \pm 2.33$ & $42.86 \pm 1.84$ & $47.07 \pm 0.51$ & 0.02 \\
Reactive Black NN & $18.92 \pm 1.1$ & $20.46 \pm 1.49$ & $21.02 \pm 1.51$ & 0.514 \\
Disp. Red BS & $22.51 \pm 1.86$ & $23.38 \pm 1.66$ & $27.32 \pm 1.47$ & 0.175 \\
\hline
\end{tabular}

Each value is mean $\pm \mathrm{SE}(\mathrm{n}=3), *$ The mean difference is significant at the 0.05 level.

TABLE 3. The effect of different dyes on the protein content of Aphanocapsa elachista.

\begin{tabular}{lcccc}
\hline \multicolumn{5}{c}{ Protein content $(\mathbf{m g} / \mathbf{m l})$} \\
\hline Dyes & $\mathbf{3}$ & $\mathbf{5}$ & $\mathbf{7}$ & L.S.D* \\
\hline Control & $30.00 \pm 0.555$ & $38.57 \pm 0.582$ & $44.00 \pm 0.774$ & 0 \\
Reactive yellow 3RN & $22.97 \pm 1.37$ & $23.69 \pm 0.847$ & $27.23 \pm 2.67$ & 0.27 \\
Disp. Orange 2RL & $22.05 \pm 0.271$ & $26.04 \pm 0.623$ & $29.43 \pm 0.801$ & 0.001 \\
Reactive Black NN & $25.73 \pm 1.18$ & $26.77 \pm 1.71$ & $29.47 \pm 1.19$ & 0.04 \\
Disp. Red BS & $21.48 \pm 0.612$ & $26.04 \pm 0.571$ & $33.84 \pm 0.455$ & 0 \\
\hline
\end{tabular}

Each value is mean $\pm \mathrm{SE}(\mathrm{n}=3), *$ The mean difference is significant at the 0.05 level.

These results are in agreement with that obtained by Sathyaprabha \& Kumaravel (2011) who reported that protein and carbohydrate concentrations as well as chlorophyll content were lower than those of the control. Also, Srashti (2013) reported that Spirulina platensis was efficient in degrading the dyes as congo red, mordant green and metanil yellow, which showed cytotoxicity at higher concentration.

\section{Azo reductase enzyme estimation}

Figure 1 showed that the azoreductase enzyme activity of Chlorella vulgaris after treatment with Disp. Orange $2 \mathrm{RL}$ was induced and estimated after 3,5 , and 7 days of incubation $(56.82 \%$, $60.73 \%$ and $62.17 \%$, respectively) as compared with the control. Also the addition of Reactive yellow 3RN induced azo reductase enzyme activity in Aphanocapsa elachista by about 47.06, 52.23 and $52.48 \%$, respectively after 3,5 and 7 days of incubation as compared with the control (Fig. 2).
The current results are in agreement with that obtained by Wen-Tung \& Ming-Der (2012) who reported that several species of Chlorella and Oscillotoria were capable of degrading azo dyes to their aromatic amines and metabolizing the aromatic amines to simple organic compounds or $\mathrm{CO}_{2}$. Some algal species were even capable of utilizing a few azo dyes as their sole source of carbon and nitrogen.

\section{FT-IR analysis of decolorized samples}

In the present work, the obtained differences in spectral intensity and the occurrence of stretched vibration in IR of the algal biomass treated with some dyes showed evident possible biosorption besides the algal degradation activities. These results are in accordance with that reported by Srashti (2013). Infrared analysis was performed to the dye compound before and after treatment by the alga to show the intensity of IR peak and to show the change in the structure of the compound. 


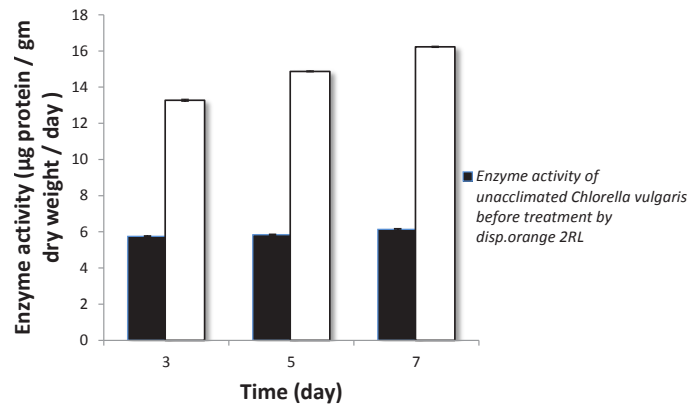

Fig. 1. Activity of azo reductase enzyme of Chlorella vulgaris before and after treatment by azo dye (Disp. Orange 2RL).

Figures 3 and 4 showed that there was a slight difference in the IR peak of the biomass of Chlorella vulgaris before and after treatment by Disp. Orange 2RL (azo dye) and Reactive yellow 3RN. These results confirmed the results of Disp. Orange 2RL degradation, where high percentage was reached (55.22\% and $31.53 \%$, respectively) after 7 days of incubation. These results may be due to the ability of this alga to induce azo reductase enzyme under azo dye stress condition and when the percentage of degradation was low the dye might be consumed by cells and/or adsorbed on the cell wall and the residue left was degraded by the alga. These results are in agreement with that obtained by Urushigawa \& Yonezawa (1977).

Figure 5 showed the Infrared spectrum of Disp. Orange 2RL before and after Chlorella vulgaris action. Results demonstrated that there was a stretching vibration of Disp. Orange $2 \mathrm{RL}$ reduced at the range of $1600-1516 \mathrm{~cm}^{-1}$ as indicated by shaded part. This was due to the degradation of Disp. Orange 2RL by Chlorella vulgaris and the percentage of degradation reached $55.22 \%$ after 7 days of incubation. These results suggest that algal action cause the cleavage of azo linkage of Disp. Orange 2RL and the formation of the aromatic amine. There were some peaks at $1342 \mathrm{~cm}^{-1}$, $2977 \mathrm{~cm}^{-1}$ in the spectra of Disp. Orange $2 \mathrm{RL}$ before treatment by alga which disappeared after treatment. These results are in agreement with those obtained by Kirso et al. (1988).

Infrared of the biomass of Aphanocapsa elachista after treatment by Reactive yellow 3RN showed reduction in azo bond within the range $1654-1542 \mathrm{~cm}^{-1}$ as indicated by the shaded part in Fig. 6. These results are in accordance with that obtained by El-Sheekh et al. (2009).

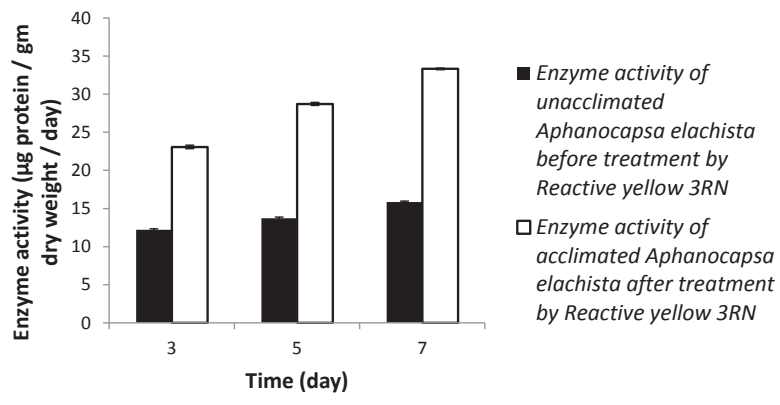

Fig. 2. Activity of azo reductase enzyme of Aphanocapsa elachista before and after treatment by azo dye (Reactive yellow 3RN).

Gas chromatography - mass spectrometry (GCMS)

Gas chromatography - mass spectrometry (GC-MS) is a technique that combines the separation properties of gas - chromatography with the detection feature of mass spectrometry. This combination facilitates the identification of the amount and type of chemicals present in a sample by ionizing chemical compounds to generate charged molecules or molecule fragments and measuring their mass-to-charge ratios (Jenke, 1996). In the present investigation, GC-MS has used for analyzing the products of degradation of Disp. Orange 2RL dye before and after treatment with Chlorella vulgaris after 7 days of incubation (Tables 4 and 5). There were some major peaks appeared before the degradation process at retention times 9.21, 23.51, 50.58, 54.95 and $55.61 \mathrm{~min}$ and after Chlorella vulgaris action, these peaks were disappeared and new peaks appeared at the retention times $6.55,10.65,13.24,22.70$ and 49.79min.

The mass spectrum fragmentation of the parent dye yield nine intermediates, which were identified as (N- methyl-1- adamantane acetamide) with $\mathrm{m} / \mathrm{z}$ 207 and (Tris (Tert-butyldimethylsilyoxy) arsane) with $\mathrm{m} / \mathrm{z} 135$, at retention time $49.79 \mathrm{~min}$ and (1 - ALLY 1-2,3- dimethoxy - 4,5 - methylene dioxybenzene or Dillapiole) with $\mathrm{m} / \mathrm{z} 222$ at retention time $22.70 \mathrm{~min}$, (2-cyclohexen-1-one,2methyl-5-(1-methylethenyl) with $\mathrm{m} / \mathrm{z} 108$ and (D-Carvone) with $\mathrm{m} / \mathrm{z} 93$ at retention time 13.24 min (6- Aza-5,7,12,14 - Tetrathiapentacene) with $\mathrm{m} / \mathrm{z} 267$ and (Cyclotetra siloxane,decamethyl) with $\mathrm{m} / \mathrm{z} 73$ at retention time 10.65 (2,5 - Dihydroxyac etophenone,bis(trimethylsilyl) ether) with $\mathrm{m} / \mathrm{z} 282$ and (Cyclotetrasiloxane,octamethyl) with $\mathrm{m} / \mathrm{z} 133$ at retention time $6.55 \mathrm{~min}$. 


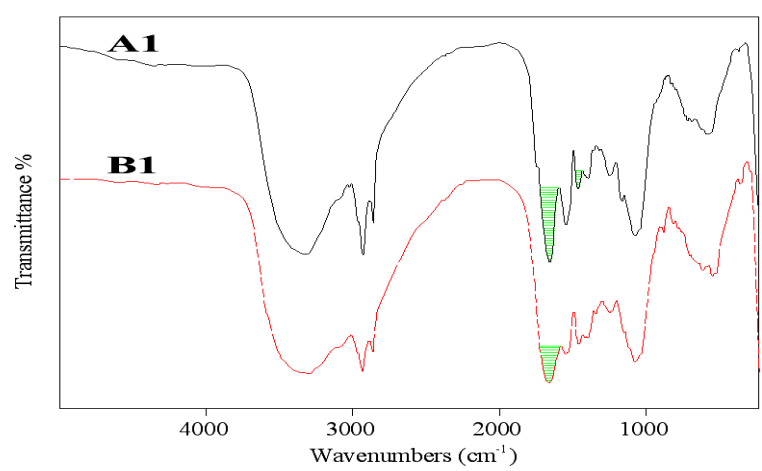

Fig. 3. Infrared of biomass of Chlorella vulgaris, (A1) Control; (B1) After treatment by Disp. Orange 2RL.

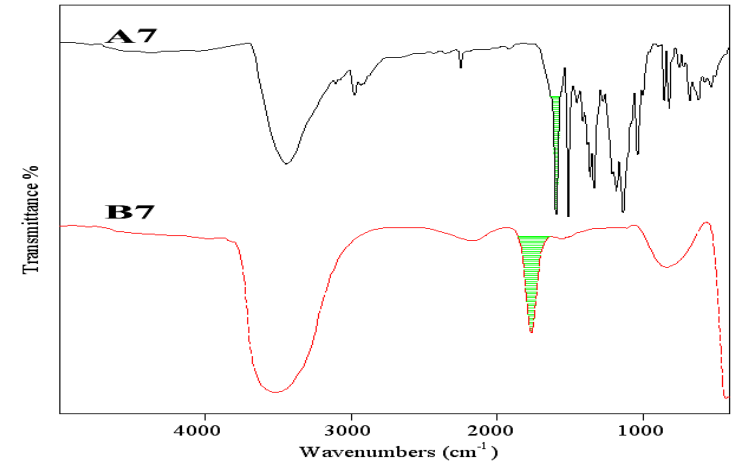

Fig. 5. Infrared spectrum of Disp. Orange 2RL, (A7) Before; (B7) After Chlorella vulgaris action.

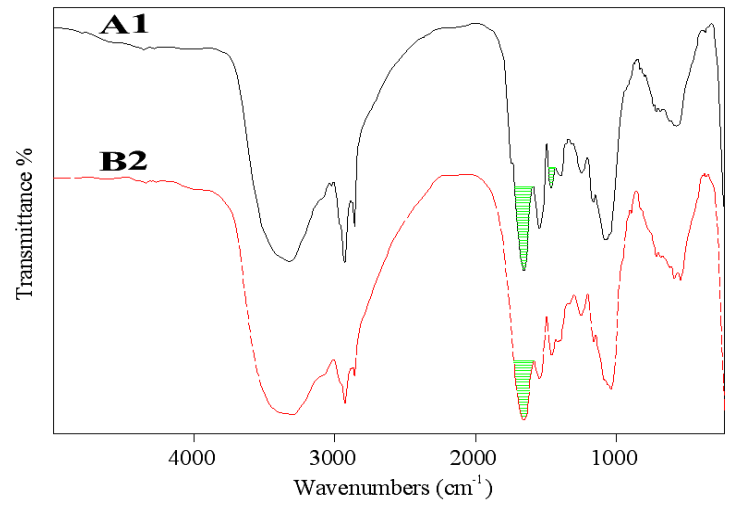

Fig. 4. Infrared of biomass of Chlorella vulgaris, (A1) Control; (B2) After treatment by Reactive yellow 3RN.

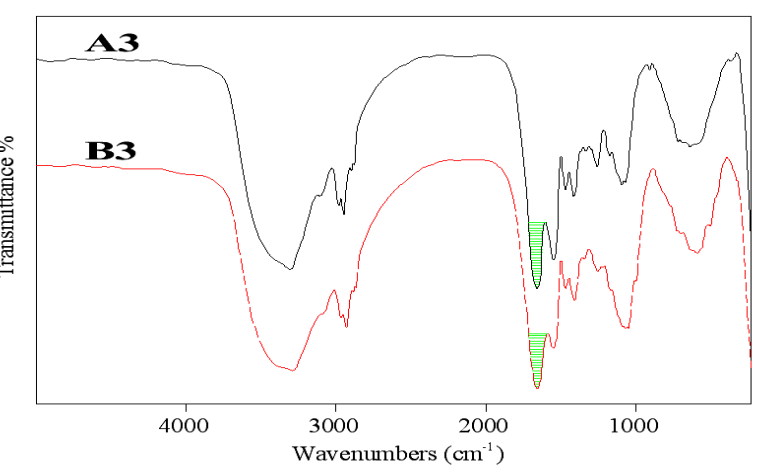

Fig. 6. Infrared of biomass of Aphanocapsa elachista, (A3) Control; (B3) After treatment by Reactive yellow 3RN.

TABLE 4. Gas chromatogram data of Chlorella vulgaris before treatment by Disp. Orange 2RL.

\begin{tabular}{|c|c|c|c|}
\hline R.T(min) & Compounds & $\begin{array}{c}\text { Area } \\
\%\end{array}$ & Quality \\
\hline 9.212 & Decamethyl tetrasiloxane $\left.\left[\mathrm{CH}_{3}\right)_{3} \mathrm{SioSi}\left(\mathrm{CH}_{3}\right)_{2}\right] 2 \mathrm{O}$ & 3.59 & 74 \\
\hline 23.517 & $\begin{array}{l}\text {-1,2,3-Propanetricarboxylic acid,2-hydroxy-,triethyl ester-\$\$ Cirtoflex } 2 \\
\text {-Acetyl triethylcitrate }\end{array}$ & 1.89 & $\begin{array}{l}83 \\
64\end{array}$ \\
\hline 50.585 & -1,2-Bis(Trimethylsilyl)benzene & 2.92 & 64 \\
\hline 54.958 & $\begin{array}{l}\text {-Neophytadiene } \$ \$ 7,11,15 \text {-Trimethyl,3-methylene-1-hexadecene } \\
\text { - 2,4a,5,8a-Tetramethyl-1,2,3,4,4a,7,8,8a octahydronaphthalen-1-ol }\end{array}$ & 8.44 & 70 \\
\hline
\end{tabular}


TABLE 5 Mass spectrometry of Disp. Orange 2RL degradation products after treatment by Chlorella vulgaris after 7 days incubation.

\begin{tabular}{|c|c|c|c|}
\hline R.T(min) & Compounds & Area \% & Quality \\
\hline 6.557 & $\begin{array}{l}\text { - 2,5 - Dihydroxyacetophenone } \\
\text { - bis(trimethylsilyl) ether } \\
\text { - Cyclotetrasiloxane,octamethyl - (CAS) }\end{array}$ & 1.95 & $\begin{array}{l}72 \\
64 \\
59\end{array}$ \\
\hline 10.65 & $\begin{array}{l}\text { - 6- Aza-5,7,12,14 - Tetrathiapentacene } \\
\text { - Cyclotetra siloxane,decamethyl -(CAS) }\end{array}$ & 4.18 & $\begin{array}{l}90 \\
87\end{array}$ \\
\hline 13.247 & $\begin{array}{l}\text { - 2-cyclohexen-1-one,2- methyl-5-(1-methylethenyl) } \\
\text { - D-Carvone }\end{array}$ & 14.87 & $\begin{array}{l}96 \\
96\end{array}$ \\
\hline 22.708 & -Dillapiole(1-ALLY 1-2,3-dimethoxy - 4,5-ethylene dioxybenzene) & 8.21 & 97 \\
\hline 49.793 & $\begin{array}{l}\text { - Tris (Tert - butyldimethylsilyoxy) arsane } \\
\text { - N- methyl-1- adamantane acetamide }\end{array}$ & 12.27 & $\begin{array}{l}47 \\
46\end{array}$ \\
\hline
\end{tabular}

Based on the enzymatic studies and GCMS analysis, the current results showed that azo bond in Disp. Orange 2RL dye was cleaved by azoreductase enzyme during the biodegradation process leading to damage in the primary chromophore as demonstrated by many investigators (Oturkar et al., 2011; Qu et al., 2012 and Khan \& Malik, 2016). The obtained results confirmed the result of degradation and decolorization of Disp. Orange 2RL dye by Chlorella vulgaris and these results are in agreement with those obtained by Shedbalkar et al. (2008), Deivasigamani \& Das (2011) and Hadibarata et al. (2014).

\section{Conclusion}

The present study confirmed the ability of microalgae to degrade the industrial dye effluents with highly decolorizing efficiency using azo reductase enzyme, thus suggesting its application to be used in many textile and paper industries. The obtained results of GC-MS confirm the biodegradation and decolorization of Disp. Orange 2RL by Chlorella vulgaris after 7 days of incubation into nine intermediates compounds. Our future study aims to find out the mechanism of biodegradation of these dyes and azo dyes by Chlorella vulgaris and Aphanocapsa elachista.

\section{References}

Abou-ElSouod, G.W. and El-Sheekh, M.M. ( 2016) Biodegradation of basic fuchsin and methyl red by the blue green algae Hydrocoleum oligotrichum and Oscillatoria limnetica. Environ. Engin. Manage. J. 15(2), 279-286.
Allen, M.M. (1968) Simple conditions for growth of unicellular blue-green algae on plates. J. Phycol. 4(1), $1-4$.

Altenburger, R., Backhaus, T., Boedeker, W., Faust, M., Scholze, M. and Grimme, L.H. (2000) Predictability of the toxicity of multiple chemical mixtures to Vibrio fischeri: Mixtures composed of similarly acting chemicals. Environ. Toxicol. Chem. 19, 2341-2347.

Anjaneyulu,Y., Sreedhara, C.N. and Raj, D. (2005) Decolourization of industrial effluents-Available methods and emerging technologies. A review. Rev. Environ. Sci. Biotechnol. 4, 245-273.

Bolch, C.J.S. and Blackburn, S.I. (1996) Isolat ion and purificat ion of Australian isolates of the toxic cyanobacterium Microcystis aeruginosa Kütz, J. Appl. Phycol. 8(1), 5-13.

Chen, C.H., Chang, C.F., Ho, C.H., Tsai, T.L. and Liu, S.M. (2008) Biodegradation of crystal violet by Shewanella sp. NTOU1. Chemosphere, 72, 1712-1720.

Couto, S.R. (2009) Dye removal by immobilized fungi. Biotechnol Adv. 27, 227-235.

Dafale, N., Rao, N.N., Meshram, S.U. and Wate, S.R. (2008) Decolorization of azo dyes and simulated dye bath wastewater using acclimatized microbial consortium-Biostimulation and halo tolerance. Bioresource Technol. 99, 2552-2558.

Deivasigamani, C. and Das, N. (2011) Biodegradation of Basic Violet 3 by Candida krusei isolated from 
textile wastewater. J. Biodegrad. 22, 1169-1180.

El-Sheekh, M.M., Abou-El-Souod, G.W. and El Asrag, H.A. (2017) Biodegradation of some dyes by the cyanobacteria species Pseudoanabaena sp. and Microcystis aeruginosa Kützing. Egypt. J. Exp. Biol. (Bot.), 13(2), 233-243.

El-Sheekh, M.M., Gharieb, M.M. and Abou-El-Souod, G.W. (2009) Biodegradation of dyes by some green algae and cynaobacteria. Int. Biodeterior. Biodegrad. 63, 699-704.

Forss, J. and Welander, U. (2009) Decolorization of reactive azo dyes with microorganisms growing on softwood chips. Int. Biodeterior. Biodegrad. 63, $752-758$

Hadibarata, T., Adnan, L.A., Yusoff, A.R.M. and Khudhair, A.B. (2014) Biodegradation of bisazo dye reactive black 5 by white-rot fungus Trametes gibbosa sp. WRF 3 and its metabolite characterization. Water Air Soil Pollut, 225, 2119.

Hadibarata, T., Yusoff, A.R. and Kristanti, R.A. (2012) Decolorization and metabolism of anthraquinonetype dye by laccase of white-rot fungi Polyporus sp. S133. Water Air Soil Pollut. 223, 933-941.

Idaka, E., Ogawa, T. and Horitsu, H. (1987a) Reductive-metabolism of amino azo benzene by Pseudomonas cepacia. Bull. Environ Contamin Toxicol. 39, 100-107.

Idaka, E., Ogawa, T. and Horitsu, H. (1987b) Oxidative pathway after reduction of $\mathrm{p}$ aminazobenzene by Pseudomonas cepacia. Bull. Environ. Contamin. Toxicol. 39, 108-113.

Jenke, D.R. (1996) Chromatographic method validation: A review of current practices and procedures. I, General concepts and guidelines. $J$. Liq. Chrom. Rel. Technol. 19, 737-757.

Karthik, V., Saravanan, K., Bharathi, P., Dharanya, V. and Meiaraj, C. (2014) An overview of treatments for the removal of textile dyes. J. Chem. Pharmaceut. Sci. 7(4), 301-307.

Kaushik, P. and Malik, A. (2009) Fungal dye decolorization: Recent advances and future potential. Environ Int. 35, 127-141.

Khan, S. and Malik, A. (2016) Degradation of Reactive
Black 5 dye by a newly isolated bacterium Pseudomonas entomophila BS1, Can. J. Microbiol. 62(3), 220-232.

Kirso, U.E., Stom, D.I., Belykh, I.I. and Irha, N.I. (1988) Transformation of carcinogenic and toxic substances in the hydrosphere (in Russian), Valgues, Tallinn, Estonia.

Kuhl, A. and Lorenzen, H. (1964) Handling and culturing of Chlorella. In: "Methods of Cell Physiology", Preston, D.M. (Ed), Vol. 1, pp.159187. Academic Press, London.

Lowry, O.H., Rosebrough, N.J., Farr, A.L. and Randall, RJ. (1951) Protein measurement with the Folin Phenol Reagent. J. Biol. Chem. 193, 265-275.

Oturkar, C.C., Nemade, H.N., Mulik, P.M. Patole, M.S. and Hawaldar, R.R. (2011) Mechanistic investigation of decolorization and degradation of Reactive Red 120 by 494 Bacillus lentus BI377. Bioresour. Technol. 102, 758-764.

Pontin, R.M.(1978) "A Key to the Freshwater Planktonic and Semi-planktonic Rotifera of The British Isles", (Sci. Pub. No.38), pp. 178. Freshwater Biological Association, London, UK.

Prescott, G.W. (1984) "How to Know the Freshwater Algae", $3^{\text {rd }}$ ed., Wm, C. (Ed.), Brown Company Publication, Iowa, USA, 384 pp.

Qu, Y., Cao, X., Ma, Q., Shi, S., Tan, L. and Li, X. (2012) Aerobic decolorization and degradation of Acid Red B by a newly isolated Pichia sp. TCL. $J$. Hazard Mate. 223-224, 31-38.

Robinson, T., McMullan, G., Marchant, R. and Nigam, P. (2001) Remediation of dyes in textile effluent: A critical review on current treatment technologies with a proposed alternative, Bioresour. Technol. 77, 247-255

Sarwa, P. and Verma, S. (2013) Decolourization of orange $\mathrm{G}$ dye by Microalgae Acutodesmus obliquus strain PSV2 isolated from textile industrial. Int. J. Appl. Sci. Biotechnol. 1(4), 247-252.

Sathyaprabha, G. and Kumaravel, S. (2011) Pannerselvem A. Analysis of antioxidant activity. J. Chem. Pharmaceut Res. 3(6), 1-6.

Sen, B., Alp, M.T., Sonmez, F., Kocer, M.A.T. and 
Canpolat, O. (2013) Relationship of algae to water pollution and waste water treatment, In: "Water Treatment In Tech.", W. Elshorbagy, R.K. Chowdhury (Ed.), pp. 335-354. Intech Publisher.

Shedbalkar, U., Dhanve, R. and Jadhav, J. (2008) Biodegradation of triphenylmethane dye cotton blue by Penicillium ochrochloron MTCC 517. J. Hazard Mater, 157, 472-473

Shyamala, A., Hemapriya, J., Kadakkan, V. and Vijayanand, S. (2014) Bioremediation of Methyl Orange, a synthetic textile azo dye by a halo tolerant bacterial strain. Int. J. Curr. Res. Aca. Rev. 2(8), 373-381.

Srashti, D. (2013) Effect of textile dyes on Spirulina platensis. J. Chem. Pharmaceut. Res. 5(4), 66-80.

Telke, A.A., Joshi, S.M., Jadhav, S.U., Tamboli, D. P. and Govindwar, S.P. (2010) Decolorization and detoxification of Congo red and textile industry effluent by an isolated bacterium Pseudomonas sp. SU-EBT. Biodegradation, 21, 283-296.

Urushigawa, Y. and Yonezawa, Y. (1977) Chemobiological interactions in biological purification system II - biodegradation of azo compound by activated sludge, Bull of Environ Contamin Toxicol. 17, 214-218.

Vymazal, J. (1995) "Algae and Element Cycling in Wetlands". CRC Press, Inc., Boca Raton, Florida, USA, pp. 689.

Wen-Tung, W. and Ming-Der, J. (2012) Evaluation of light irradiation on decolorization of azo dyes by Tsukamurella sp. J8025. Appl. Mech. Mat. 145, 304-308.

Xu, S. and Nirmalakhandan, N. (1998) Use of QSAR models in predicting joint effects in multicomponent mixtures of organic chemicals. Water Res. 32, 2391-2399.

Yamagishi, T. (1992) "Plankton Algae in Taiwan (Formosa)". Uchida Rokakuho Press, Tokyo, Japan, pp. 252.

(Received 17/1/2018; accepted 11/4/2018) 
التحلل الحيوى لبعض الصبغات بواسطة بعض الطحالب الخضراء والخضراء المزرقة

\section{Chlorella vulgaris و Cyanobacterium Aphanocapsa elachista}

مصطفى محمد الشيخ(1)، غادة وجيه (بو السعود(2) و هيام الأسرج(2)

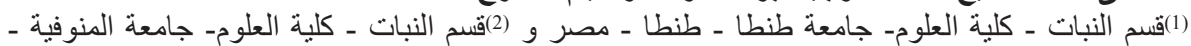

المنوفية - مصر.

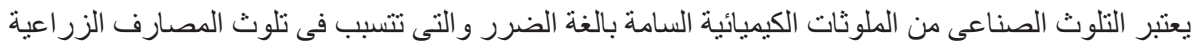

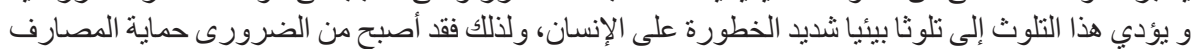

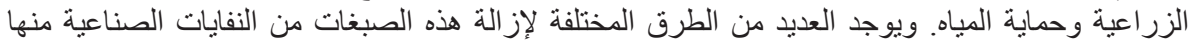

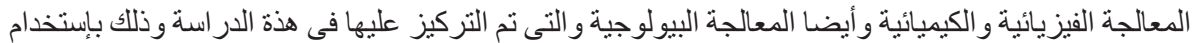

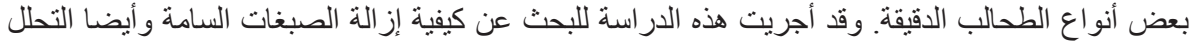

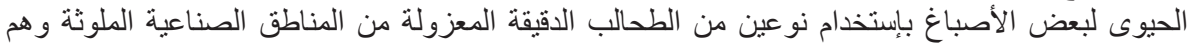

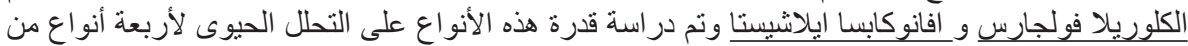

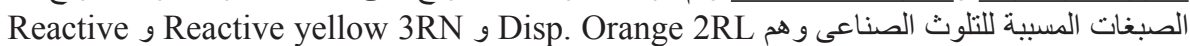

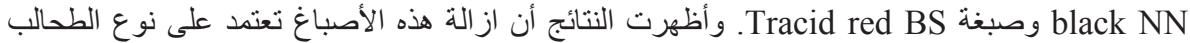

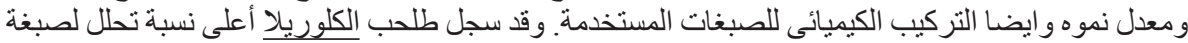
بنسبة Disp. Orange 2RL (Azo dye)

.49.16\% بنسبة reactive yellow 3 RN (Azo dye)

أيضا تم دراسة تأثثر انزيم azo reductase الموجود في الطحالب و المسؤل عن تكسير مركبات الأزو

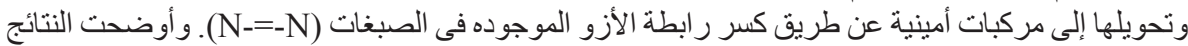

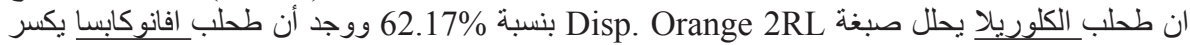

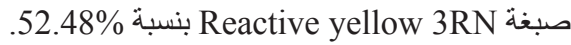

و ايضا تم در اسة نو اتج التحلل الحيوى عن طريق التحليل الطيفى واستخدام الاشعة تحت الحمر اء.

IF analysis and Gas chromatogram-mass spectrometry analysis. 